\title{
Archaeological Testing of Sites 41RT128 and 41 RT129 Robertson County, Texas
}

Joe T. Denton

Follow this and additional works at: https://scholarworks.sfasu.edu/ita

Part of the American Material Culture Commons, Archaeological Anthropology Commons, Environmental Studies Commons, Other American Studies Commons, Other Arts and Humanities Commons, Other History of Art, Architecture, and Archaeology Commons, and the United States History Commons

Tell us how this article helped you.

This Article is brought to you for free and open access by the Center for Regional Heritage Research at SFA ScholarWorks. It has been accepted for inclusion in Index of Texas Archaeology: Open Access Gray Literature from the Lone Star State by an authorized editor of SFA ScholarWorks. For more information, please contact cdsscholarworks@sfasu.edu. 


\section{Archaeological Testing of Sites 41RT128 and 41 RT129 Robertson County, Texas}

\section{Licensing Statement}

This is a work produced for the Texas Department of Transportation (TxDOT) by the report producer. TxDOT and the report producer jointly own all rights, title, and interest in and to all intellectual property developed under TXDOT's contract with the report producer. The report may be cited and brief passages from this publication may be reproduced without permission provided that credit is given to both TXDOT and the report producer. Permission to reprint an entire chapter, section, figures or tables must be obtained in advance from either the Supervisor of the Archeological Studies Branch, Environmental Affairs Division, Texas Department of Transportation, 125 East 11th Street, Austin, Texas, 78701 or from the report producer. 
ARCHAEOLOGICAL TESTING OF SITES 41RT128 AND 41 RT129

ROBERTSON COUNTY, TEXAS

BY

Joe T. Denton

Texas

State Department of Highways and Public Transportation

Highway Design Division

June 1983 


\begin{abstract}
Testing was undertaken in November 1982 of two sites on State Highway 6 between Hearne and Bryan in order to determine site depth, cultural context, and archaeological significance. A rchaeological Site 41RT128 was typified by numerous bone fragments of Bos species, and Site 41RT129 was evidenced by a lithic scatter on a sandy hilltop on the south bank of Pin Oak Creek.
\end{abstract}

Testing indicated that Site 41RT128 was a late nineteenth century farm site and Site 41RT129 was a prehistoric lithic manufacturing site and possible campsite. Because of the depth and nature of these sites it was determined that no further work is warranted.

\title{
INTRODUCTION
}

Archaeological Sites 41RT128 and 41RT129 were reported in September 1980 by Daymond Crawford of the State Department of Highways and Public Transportation (SDHPT) and were recommended for testing. Testing was conducted by the author and personnel provided by the local SDHPT office during the period November 8 through November 23, 1982, in accordance with the Procedures for the Protection of Historic and Cultural Properties (36 CFR, Part 800). Theobjective for the tests was to determine eligibility to the National Register of Historic Places as prescribed by law, and to determine the nature of the deposits and cultural context.

Archaeological Site 41RT128 is located on the south side of the State Highway 6 roadway on a terrace north of a small unnamed dry creek 2.8 miles south of Hearne. Presently the area is pasture and scattered woodlands. The soils are loamy sands and sandy clays and are partially disturbed from agricultural clearing. Presence of cultural materials was noted from recent disturbances of the soil by underground cables. Observed materials included bones from Bos species, recent cultural refuse of glass and metal, and an occasional flint flake or chip.

Archaeological Site 41RT129 is located on the south bank and hilltop above Pin Oak Creek and west of State Highway 6, 2.2 miles south of Hearne. Based on information provided by local relic collectors the site extended a minimum of 1000 feet to the west toward the Little Brazos River. The hilltop overlooks the Little Brazos River Valley. At present the area is covered by improved coastal pasture, and it has been cultivated in the past. Presumably the area was once woodlands. Cultural debris was evident in areas of sheet wash on the lower slopes and in gopher mounds on the hilltop. 


\section{ARCHAEOLOGICAL BACKGROUND}

Archaeological work prior to the SDHPT field work has been conducted in portions of Robertson County primarily by the University of Texas at Austin in conjunction with the Upper Navasota Reservoir and Twin Oak and Oak Knoll Projects (Prewitt 1974, 1975; Prewitt and Grombacher 1974).

Based on information provided by these projects, Prewitt (Prewitt 1975: 10-12) has presented a tentative guide to the cultural sequence in the Central Texas area. The sequence as presented shows a strong influence in the Early Archaic Period between the area and Central Texas and a strong influence between the area and East Texas in the Late Archaic Period continuing into the post-Archaic Period.

\section{PROCEDURES}

All investigations were either hand excavations or auger tests. Test units were excavated by shovel and trowel and the excavated soil was screened through 1/4" hardware cloth. All units were excavated in arbitrary $10 \mathrm{~cm}$ levels. Recovered material was bagged and labeled as to provenience and returned to the SDHPT lab for analysis. Test unit size varied from 1 by 1 meter, 1 by 2 meter, and 2 by 2 meter units. Unit location was based on two factors: soil depth as indicated by auger tests and surface indications.

SITE 41RT128

\section{Site Description}

Testing of Archaeological Site 41RT128 consisted of one 1 by 1 meter unit and one 2 by 2 meter unit (Fig. 1). The area to be tested was limited as the SDHPT had only acquired 20 feet of additional right-of-way. Outside of the right-of-way in an area where a telephone cable had been buried were numerous bone fragments and an occasional flake. The presence of this material had led to the initial speculation that the site could have been a bison kill site or a butchering site. Condition of bone ranged from very porous and soft to hard and dense. The bone also showed some evidence of burning. 


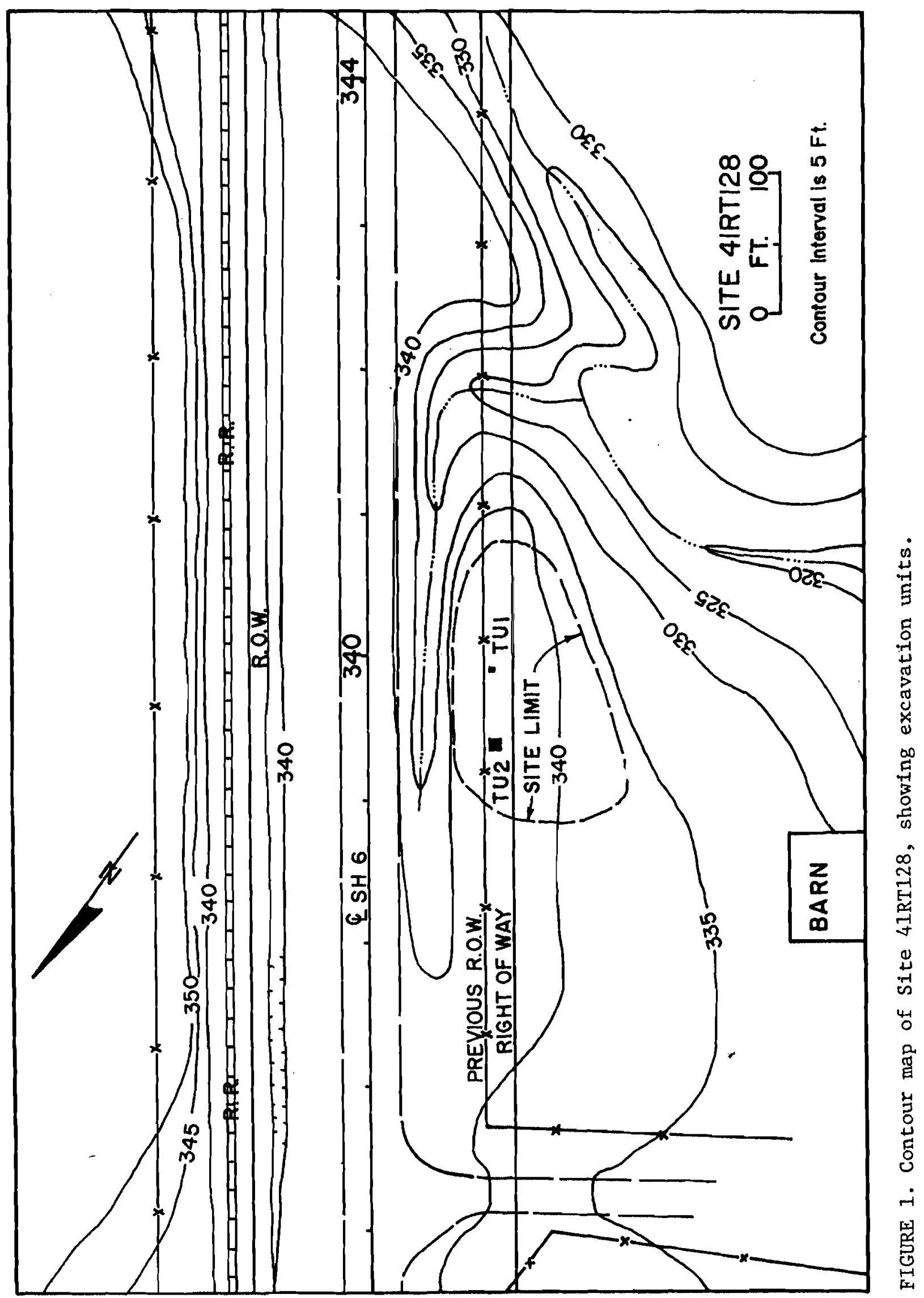


The soils are a loamy sand and a sandy clay, and the maximum depth is approximately $35 \mathrm{~cm}$ to the top of the clay (Fig. 2). The loamy sand is mottled with clays and contains numerous rodent burrows. The top organic zone is less than $4 \mathrm{~cm}$ thick.

\section{Artifact Distribution}

Bone and historic artifacts dominated in a 11 levels excavated. Bone occurred throughout a 11 levels with a slight increase in Level 2 and a slight decrease in Level 3. Historic material recovered consisted of historic ceramics including Bennington Ware, bottle glass dating to the late $1800 \mathrm{~s}$, a ratchet-type burner for an oil-type lamp, a large piece of metal which possibly could be a portion of a early horse-drawn farm implement, and nails. The nails recovered were cut nails and were most numerous in Level 3 just above the clay.

Evidence of prehistoric occupation consisted of 25 flakes from all three levels and one distal tip of a biface in Level 1. The distribution and general lack of flakes and tools indicate that the prehistoric occupation was probably incidental with the faunal material.

The bone, totaling 1089 grams, was, with one exception, probably cow. None of the bone or bone fragments could be definitely identified as cow or bison. The only exception to the Bos species was a canine tooth from a medium size carnivore. Some of the bone is burned but none exhibits any butchering.

Table 1 presents the provenience of the recovered artifacts.

Table 1. Artifact distribution from Site 41RT128.

\begin{tabular}{lccccccccc}
\hline & Bone & & Flakes & Biface & Ceramics & Glass & Metal & Nails & Brick \\
Level 1 & 315.5 & $\mathrm{~g}$ & $\mathbf{1 7}$ & $\mathbf{1}$ & 3 & 8 & $\mathbf{1}$ & 5 & $\mathbf{1}$ \\
Level 2 & 487.0 & $\mathrm{~g}$ & 7 & 0 & 5 & 9 & 8 & 5 & 5 \\
Level 3 & 286.5 & $\mathrm{~g}$ & 7 & 0 & 3 & 9 & 4 & 15 & 0 \\
\hline \hline
\end{tabular}

Conclusion and Recommendations

Archaeological Site 41RT128 appears to be a historic component located coincidentally with a sparce prehistoric component of unknown affiliation. The prehistoric component is presumably a terrace campsite possibly limited 


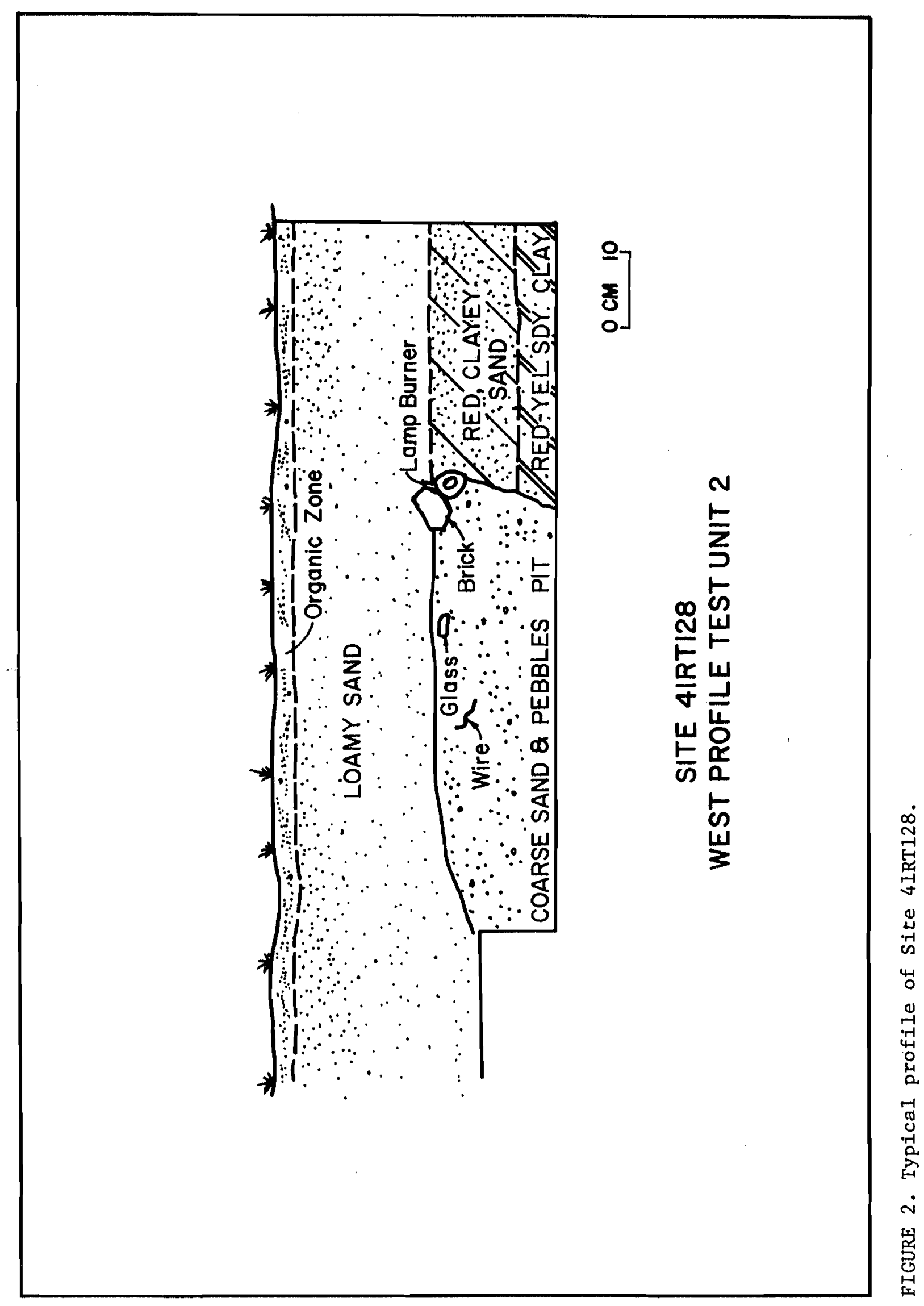


to a one-time use. The historic component appears to be the result of a nineteenth century farming operation of undetermined date. The lack of any artifacts from the early part of the twentieth century suggests a terminal date for the historic component of around 1900 A.D. The lack of evidence of butchering, the fact that some of the bone was burned, and the disturbed soil indicate that this was probably a dump site for waste carcasses.

On the basis of the test excavations it is believed that the site as evidenced by the material within the SDHPT right-of-way does not meet the criteria for inclusion within the National Register of Historic Places and does not warrant any further investigation.

SITE 41RT129

Site Description

Archaeological testing of Site $41 \mathrm{RT} 129$ consisted of three test units, one 2 by 2 meter and two 1 by 2 meter units, as well as numerous augertests (Fig. 3). The maximum soil depth as derived by auger tests is $40 \mathrm{~cm}$. The area acquired by the SDHPT consists of an additional 50 feet of right-ofway. This is only a small portion of the site and the information from the test limits the discussion of the site's significance.

The soils consist of sandy loams and sandy clays. The sandy loam is homogeneous down to the contact at approximately $40 \mathrm{~cm}$ with the clay. The homogeneous nature of the soil results presumably from agricultural use and from mixing by the active population of rodents.

Artifacts

\section{ARTIFACT DISTRIBUTION}

Surface indications were limited to areas of sheet wash, gopher mounds, and the recent relocation of right-of-way fences. These indications consisted of flakes and one biface fragment. Also noted on the surface was an occasional glass fragment.

The historic materials present occurred as deeply as $30 \mathrm{~cm}$ and consisted primarily of bottle fragments and cut nails. Also recovered was a creamcolored ceramic stoneware fragment and a single fragment of window glass. 


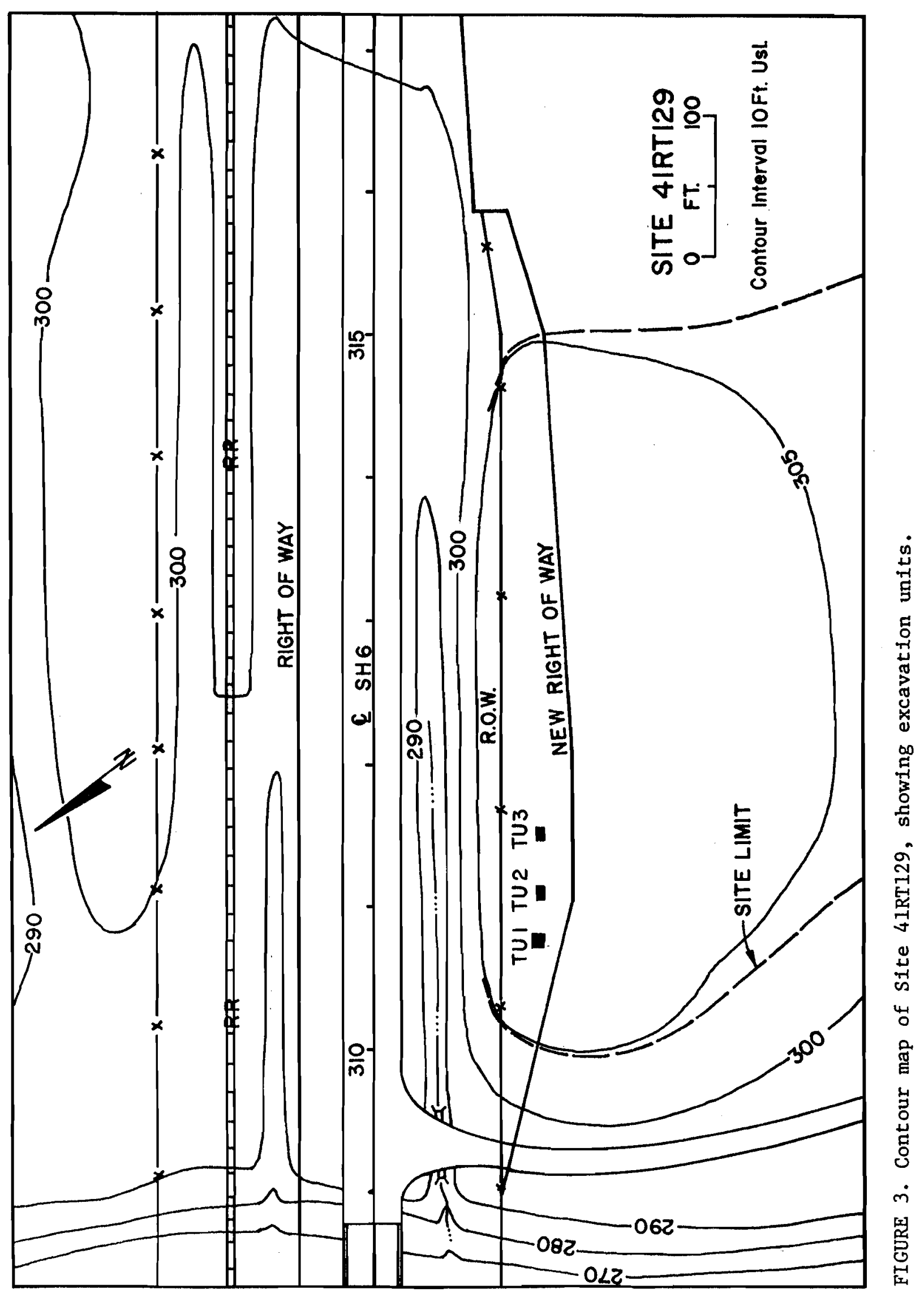


Artifacts of prehistoric origin include 3 projectile points, 7 biface fragments, and 2 cores (Fig. 4). The debitage consists of 534 flakes and chips.

Table 2 presents the provenience of the excavated artifacts.

Table 2. Provenience of excavated artifacts, Site 41RT129.

\begin{tabular}{lccccc}
\hline & Flakes & $\begin{array}{c}\text { Projectile } \\
\text { Points }\end{array}$ & $\begin{array}{c}\text { Biface } \\
\text { Fragments }\end{array}$ & $\begin{array}{c}\text { Cores } \\
\text { Artifacts }\end{array}$ \\
Level $\mathbf{1}$ & 141 & 0 & $\mathbf{1}$ & 0 & $\mathbf{2}$ \\
Level 2 & 169 & $\mathbf{1}$ (Alba) & $\mathbf{2}$ & $\mathbf{1}$ & 5 \\
Level 3 & 159 & 0 & $\mathbf{2}$ & $\mathbf{1}$ & 2 \\
Level 4 & 65 & $\mathbf{1}$ (Lange) & 2 & $\mathbf{1}$ & 0 \\
\hline \hline
\end{tabular}

PROJECTILE POINTS

Alba (Fig. 4A)

Provenience: Test Unit 2, Level 2

The tip and a portion of the blade are missing. The blade edges are concave with widely expanding barbs. The stem is slightly contracting and the base is squared. The point is well made and has been totally bifaced.

Lange (Fig. 4B)

Provenience: Test Unit 3, Level 4

This complete specimen has a triangular blade with straight converging edges and prominent shoulders. The stem is straight to slightly expanding with a straight base. The base appears to be the original flake platform from which the point was manufactured. 




A


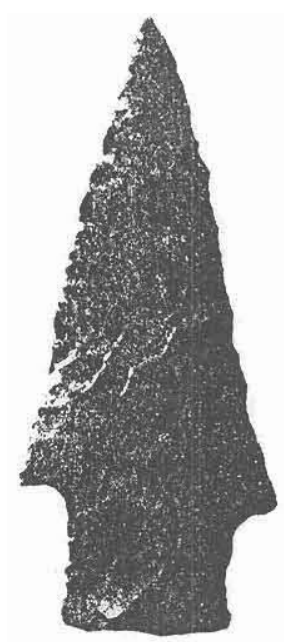

B

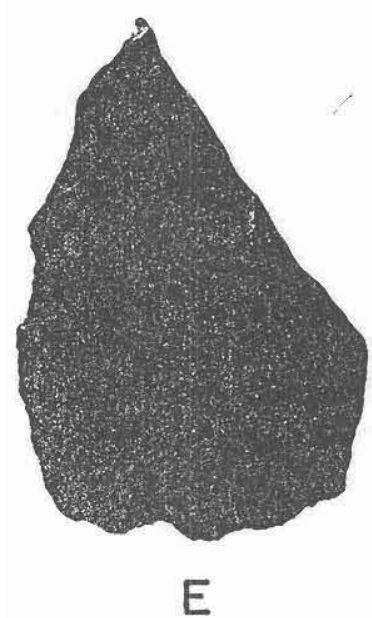

$E$

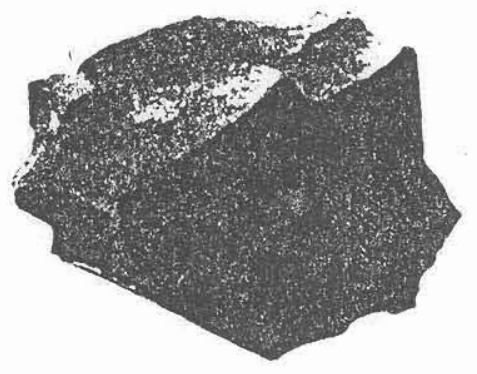

H

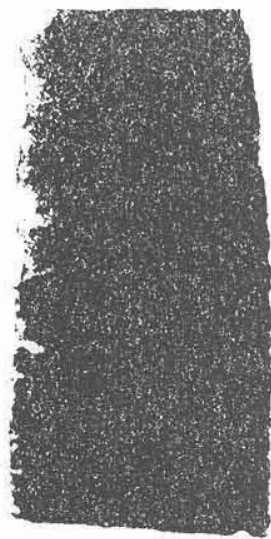

C

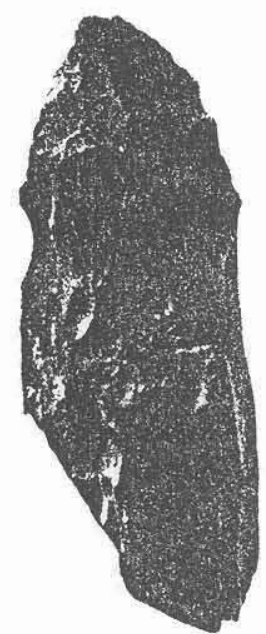

$\mathrm{F}$
G

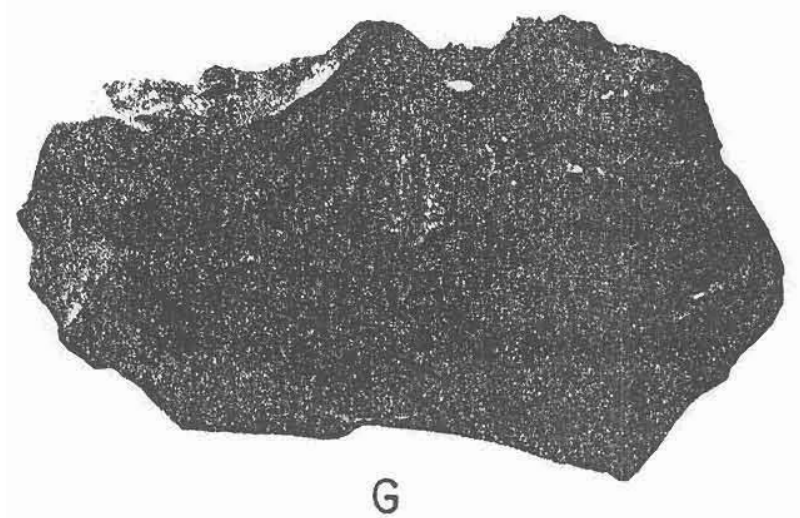

FIGURE 4. Prehistoric artifacts from Site 41RT129. A, Alba arrowpoint; $B$, Lange dart point; $C$, miscellaneous dart point fragment; $D$, thinned biface fragment; E-G, thick bifaces; $\mathrm{H}$, core. 
Miscellaneous Dart Point (Fig. 4C)

Provenience: Test Unit 1, Surface

This large projectile point is incomplete and is missing the distal tip and a portion of the blade. Unlike the other two projectile points, it is made of Edwards Plateau flint. (The Alba and Lange are made from local cherts.) The blade is thin and lenticular in cross-section, with straight edges that are only slightly converging. The base is straight and thinned by small flakes. There is no evidence of grinding in the proximal area. The edges on the medial portion of the specimen are noticeably blunted as is possible from use such as might be the case with a hafted knife.

\section{OTHER BIFACES}

Thinned Biface Fragment (Fig. 4D)

Provenience: Test Unit 3, Level 4

This specimen, although fragmentary, is judged to be a probable projectile point that was snapped during manufacture. The blade is lenticular in cross-section and has slightly convex edges. One surface of the blade exhibits numerous hinge flakes indicative of problems in manufacture.

Thick Bifaces (Fig. 4E-G)

Provenience: Test Unit 1, Levels 1, 2, 3

Three bifaces were recovered from the same unit. All appear to have been manufactured from cobbles of local cherts by core reduction techniques. Cortex is evident on several surfaces of each specimen. Flaking is by percussion and each appears to have been rejected due to failures.

Three biface fragments were also recovered from the test unit which were too incomplete for analysis. 
CORES (Fig. 4H)

Provenience: Test Unit 3, Levels 2, 3, 4

Three cores were recovered from Test Unit 3. Two were local flint cobbles which exhibited flaking on several faces. The illustrated specimen appears to have been utilized for flake blade removal from a rejuvenated core.

Conclusions and Recommendations

Conclusions concerning Site $41 \mathrm{RT} 129$ are limited due to the brevity of the test and the small area of the site tested.

The projectile points demonstrate that there was a long-term cultural use of the area from the Archaic Period into the Late Prehistoric Period. The artifact assemblage as recovered indicates that the area tested is primarily a lithic reduction area and possibly a campsite. No features or burned rocks were noted during the test but this fact does not preclude their existence.

The shallow nature of the soil deposits and disruptions from rodent and agricultural practices minimize the significance of the site. It is possible that there are other areas of deeper soils outside the investigation area.

The large size of the site could be useful, however, in a large-scale excavation to discern horizontal differences, temporal changes, and differential activity areas.

As evidenced by data gathered during the test, it is believed that the investigation area does not meet the criteria for inclusion in the National Register and does not warrant any further investigation. 


\section{REFERENCES CITED}

Prewitt, Elton R.

1974 Upper Navasota Reservoir: An Archeological Assessment. Texas Archeological Survey Research Report 47. The University of Texas at Austin.

1975 Upper Navasota Reservoir: An Archeological Test Excavation at the Barkley and Louis Sadler Sites. Texas Archeological Survey Research Report 53. The University of Texas at Austin.

Prewitt, Elton R., and K.A. Grombacher

1974 An Archeological and Historical Assessment of the Areas to be Affected'bythe Proposed Twin Oak and Oak Knoll Projects, East Central Texas. Texas Archeological Survey Research Report 43. The University of Texas at Austin. 